\title{
DIE KERK SE BEMOEIENIS MET DIE JEUG
}

DS. C. L. VAN DEN BERG.

\section{A. DIE OPDRAG EN DIE TERREIN.}

Daar is nie nog 'n saak waaroor die kerk in sy Wet en Bepalings so kort en so wyd en so vaag praat soos oor die bemoeienis van die kerk met die jeug nie. Op een bladsy (33) en in vier artikels (55-58) word klaargespeel met die opdrag aan drie rade, te wete Belydende Jeug, Kategese en Opvoeding en Onderwys. Wat méér is: van hierdie vier artikels sê twee niks meer nie as dat die kerk hierin verantwoordelikheid aanvaar vir kerk en volk. Daar bly dus twee artikels oor waarin die opdrag aan drie rade vervat is vir die nakoming van hierdie verantwoordelikheid. Een van hulle (56) handel oor die Rade vir die Belydende Jeug en vir Kategese. Dié bestaan uit twee afdelings. Die eerste stel die taak van die twee rade, blykbaar in die algemeen, want in die tweede afdeling lui dit: „Die rade het insonderheid die taak ... " Maar nou is die merkwaardige dat dié algemene taakstelling in die eerste afdeling met betrekking tot albei rade met groot nadruk die jeug van die kerk in die oog het, eendersyds die wat reeds belydenis van die geloof gedoen het en andersyds die wat nie belydenis van die geloof gedoen het nie. Maar in die tweede afdeling waarin die kerk dus die taak in besonderhede uiteensit, en waarin daar sprake is, eerstens, klaarblyklik met die oog op die Raad vir Kategese, van verkondiging aan en onderrig van die jeug, en tweedens en derdens, blykbaar aan die adres van die Raad vir die Belydende Jeug, van ,,jeugwerk", ontspanning, vrye tydsbesteding en aktiewe deelname aan die lewe van die ge. meente, ontbreek die kwalifikasie ,van die kerk" geheel en al. Sou die kerk kon bedoel dat die taak in die algemeen tot die jeug van die kerk beperk is, maar dan ,insonderheid" 'n terrein moet bestryk wat aan alle kante ooplê na die wye wêreld toe? Of sien die ,insonderheid" alleen op 'n aanduiding van enkele riglyne vir die verrigting van die taak wat in die eerste afdeling reeds tot die jeug van die kerk beperk is? Dit lyk darem meer logies. Maar wat word dan van ons herhaalde versekering dat dit ons hierin gaan om die jeug van die kerk én volk? Is ons aanvaarde medeverantwoordelikheid vir die jeug van die volk nagekom met die bemoeienis van die Raad vir Opvoeding en Onderwys met onderwysbeleid en leerplanne?

Die wydsheid en vaagheid van die opdrag weerspieël die onbegrensheid en omvattenheid van die terrein wat hy in die oog het. Is dit elders al moeilik, by die jeug word dit 'n haglike onderneming om die grens tussen kerk en wêreld te bepaal. 
Is die jeug, ook die sogenaamde „Jeug van die kerk” nie wêreld op pad kerk-toe nie? En as die kwalifikasie bykom: „Jeug van die kerk wat reeds belydenis van die geloof in die gemeente afgelê het", het hulle dan opgehou om "wêreld op pad kerk-toe" te wees? Het ons genoeg vertroue in ons kategese en toelatingsprosedure om dit te kan beweer? Of geld vir hulle ook nog maar onverminderd die noodsaak ,,dat 'n mens julle (weer) die eerste beginsels van die woorde van God moet leer" (Heb. 5:12)? Andersom gestel: Is al die kerk se bemoeienis met die jeug nie uitgaan na die wêreld toe in eintlike sin nie? Is die jeug nie in elke eeu vir die kerk die opdoemende horison van die „uiterste van die aarde" - in die ruimte én in die tyd nie? Maar ook in kwalitatiewe sin: „die uiterste”, die ergste waartoe die aarde in staat is? En sou die kerk in sy gestuur-wees na die uiterste van die aarde kon selektief te werk gaan? Hom beperk tot „dié wat reeds belydenis van die geloof in die gemeente gedoen het"? Of tot die wat deur gelowige (of bygelowige) ouers ten doop gebring is?

Die vraag is: Is die kerk se bemoeienis met die jeug pastoraat, dit wil sê versorging van wat binne is, of apostolaat, dit wil sê bewoënheid om wat buite is?

Ek wil graag as eerste kwalifikasie in ons besinning oor die kerk se bemoeienis met die jeug die stelling neerlê: Hierdie arbeid word verrig op 'n terrein: waar (i) die grens tussen kerk en wêreld nog bestaan uit weinig meer as ,'n vaste vertroue op die dinge wat ons hoop, 'n bewys van die dinge wat ons nie sien nie"; met ander woorde vir die vleeslike oog nie bestaan nie; waar (ii) die pastoraat van die kerk geen ander vorm kan aanneem as bewoënheid oor wat nog buite is nie, en hom ook nie anders kan uit as in hartstogtelike apostolaatsbeoefening nie; (N.B.! Die opdrag: ,laat my lammers wei”, kom op 'n stadium in die tydsverloop van die gebeure toe daar in elk geval nog geen sprake is van jeug wat reeds belydenis afgelê het of van gedoopte kinders van die gemeente nie) waar (iii) die teologie self te staan kom voor die eis: „elkeen wat sy „,siel” om my ontwil verloor, hy sal dit red," (Luk. 9:24) en miskien geen wyser woord kan spreek as die swyende aanbieding van 'n beker koue water nie. Maar in hierdie beker koue water, uitgereik oor die rand van die teologie, op 'n terrein waar die grens tussen kerk en wêreld uit die gesigsveld verdwyn ,tasbare beliggaming van die één-wees van die apostolaat en die pastoraat van die kerk, klop die hart van die evangelie. Daar is geen ander terrein nie waar die kerk so wesenlik bloot staan voor die gevaar, deur Heinz Zahrnt so pittig uitgebeeld in die skildering van die teoloë wat mekaar se oë laat skitter - en mekaar se teologiese mage rond laat uitbult 
- met verruklike appels van suiwere teologie, direk in die paradys gepluk, terwyl Adam en Eva van honger vergaan tussen die dorings en distels.

Teoloë moet daarop bedag wees dat daar ook in die teologiese paradys verbode vrugte sal wees, vrugte van kennis van goed en kwaad, waarvan die pluk niks anders sal wees as flagrante ongehoorsaamheid nie.

\section{B. DIE SITUASIE MET DIE JEUG VANDAG.}

Daar ís losbandigheid onder die jeug van ons tyd. Dié was daar ook in ons eie jeug — in die oorlogsjare. Dié was daar ook op die saamtrekpunte van die bevolking in die vorige eeu - die diamant- en goudvelde. Dié was daar in die vroeë dae van die volksplanting aan die Kaap, sn in die dae van Calvyn, en van Paulus, én van Plato. Dat die kerk hom te bekommer het oor die probleem van die weerbarstigheid van die jeug is nie 'n verskynsel van ' $n$ bepaalde tyd nie, maar hou verband met die inbring van die mens in die koninkryk van die hemele (onder die heerskappy van God), en is wesenlike deel van die kerk-wees van die kerk.

Wat in ons tyd bygekom het, is die sogenaamde permissiwiteit. Maar die woord en die verskynsel permissiwiteit sê nie iets oor die jeug nie, (behalwe as dit is dat die jeug aan homself oorgelaat, dit wil sê aan die duiwel uitgelewer is) maar oor die geslag wat die ouers van die jeug is. Permissief beteken om maar toe te laat. Daar is nie so-iets soos permissiewe jeug nie. Daar's net permissiewe ouers, permissiewe gemeenskappe (en dié is gemaak deur volwassenes) permissiewe owerhede, ensovoorts. Die verskynsel permissiwiteit beteken nie dat die jeug losbandiger is as in enige ander tyd nie, maar dat die jeug wat uiteraard nie minder losbandig is as in ander tye nie, in hierdie tyd in die steek gelaat is deur 'n ouer geslag wat onseker geword het, te onseker om met gesag te beslis tussen reg en verkeerd. Permissiwiteit is 'n refleksie op die jeug - maar op die jeug van gister. Dis óns. As na die jeug van ons tyd gekyk word, kan 'n trop goed gesê en beweer en gefluister en geskreeu word - waarin ek weinig geinteresseerd is. Want as dit 'n kyk met die oë van die kerk is, kan daar net één waarheid die ganse uitsig oorheers, naamlik „Ek is ' $\mathrm{n}$ jaloerse God wat die misdade van die vaders besoek aan die kinders, aan die derde en aan die vierdie geslag van die wat My haat."

En dié permissiwiteit het meegebring dat daar meer openlikheid, meer luidrugtigheid, minder skroom, minder aarseling en gevolglik seker ook 'n bietjie meer welslae in die najaag van die 
boosheid is as wat ons in ons jeug op ons kerfstok kon plaas. Maar meer welslae in die najaag van die boosheid beteken nou eenmaal ook meer verskeuring en verminking, meer pyn en leed, meer verdriet en uitsigloosheid op die drumpel van die lewe as waaraan ons blootgestel was. En dit op sy beurt verhoog die behoefte aan ontvlugting; waarvoor die permissiewe gemeenskap 'n wye verskeidenheid middele voorsien. Só bevind die jeug van die permissiewe gemeenskap hom in die maalstroom van 'n bose kringloop. In die oë van die kerk kan daar by die aanskouing van dié skouspel net ontferming wees. Hier skreeu die wêreld, vir wie God liefhet, om barmhartigheidsdiens, diakonaat.

Origens moet die meer openheid, minder skroom, ook in die vertoning van die verskeurdheid en verminktheid, en in die erkenning van die drang tot ontkoming daaraan, vir die kerk as 'n bate aangestip word. Maar dan 'n kerk wat nie ook nog vir die jeug die skouspel van dieselfde permissiwiteit, net agter 'n ander masker, vertoon nie. Die jeug is weinig geholpe met 'n kerk wat hom te verstane gee dat sy verskeurdheid en verminktheid Gode welgevallig is. Wat hy moet verneem - en net by die kerk kan verneem - is dat God hierdie verskeurdheid en verminktheid haat, daarteen tot die dood toe stryd voer, dié stryd ook beslissend gewen het, en in Jesus Christus hierdie verskeurde en verminkte menswees vir ewig onherroeplik héélgemaak het.

Laat die kerk hier begin in sy kommer oor die jeug: by die vraag na die gehalte van ons prediking, na die skouspel van die lewe van die gemeente in die wêreld, na die eerlikheid van die eie onderwerping aan die gesag wat dié permissiewe wêreld met sulke smartlike gevolge verwerp het. Verby is die dae vir goed - Gode sy dank - dat die mense, en veral die jeug, geïmponeer is deur swart klere of galmende stemme.

Gelukkig wys die Bybel self ons die pad uit die moeras van die permissiewe gemeenskap uit: Ps. 78:3-8. Hier is die enigste sinvolle uitgangspunt vir doelgerigte bemoeienis van die kerk met die jeug van kerk en volk: dat seuns en dogters van verlore - of half-verlore - seuns, gelowige vaders en moeders sal word vir die jeug van môre.

Ek ken die res van die Westerse wêreld nie, maar in SuidAfrika loop daar binne-in hierdie permissiewe tyd tienduisende seuns en dogters rond wie se teenwoordigheid dit vir my maklik maak om die uitdaging van hierdie taak met geesdrif te aanvaar. Want hulle is die lewende bewyse van die toereikendheid van die toerusting van die evangelie van Jesus Christus om beskerming te verleen en weerbaar te maak, in die aangesig van watter bedreiging ook. En om die bybring van daardie toerusting gaan dit in die taak waarmee ons besig is. 


\section{ENKELE OORWEGINGS WAT TER GELDING MOET KOM.}

1. Met die instelling van ,'n Raad vir die Belydende Jeug met taak die leiding en voorligting van die jeug van die kerk wat reeds belydenis van die geloof in die gemeente gedoen het, vir hulle dienswerk in die wêreld," (Kerkwet art. 56) gee die kerk duidelike blyke van die oordeel dat die doop van kindertjies van die gelowiges, die daaropvolgende onderrig deur die ouers en deur die kategese van die kerk, die belydeniskatkisasie aanvullend tot die prediking in die erediens, die toelating tot die openbare geloofsbelydenis en die daaropvolgende deelname aan die nagmaal en die normale ampsbediening van die kerk nie genoegsame toerusting was vir hulle dienswerk in die wêreld nie. Die betrokke raad moet leiding en voorligting gee oor hoe by dit alles nog aangevul kan word. Dit is asof die kerk in die arbeid aan die Belydende jeug nog weer 'n hand uitstrek by ouers, verantwoordelik of onverantwoordelik, kategese, goed of half sleg, ampsbediening, konsensieus of onverskillig, verby, om wat waar ookal op die pad agterweë gebly het, by te bring, om sodoende nog 'n laaste greep te maak na die ouers van môre op die drumpel van volwassenheid. Dit lê goed in lyn met wat ons in Ps. 78 gehoor het. Maar dit beteken dat die raad wat hiervoor in die lewe geroep is blootgestel is aan verwyte van twee teenoorgestelde kante: eendersyds oortreding op gebiede waarvoor daar voorsiening gemaak is, en andersyds uittrede buitekant gebiede waarvoor die kerk in sy normale werkspatrooon voorsiening gemaak het.

2. Dikwels word verneem: 'n jong mens is ook maar net 'n lidmaat van die kerk; jong mense geniet dit om besondere aandag te kry; die kerk doen meer kwaad as goed deur hom te sterk in die mening dat hy iets besonders is. Die stelling hierin vervat, wil ek ten sterkste ontken. $\mathrm{Hy}$ is in verreweg die meeste gevalle nie maar net 'n gewone lidmaat soos al die volwassenes nie, want (i) hy het nooit die stem van sy vader aan die huistafel 'n hoofstuk uit die Bybel hoor lees nie (ii) Hy het as gevolg van skofwerkery van sy vader en om ander redes nooit die andersheid van die Dag van die Here leer ken nie (iii) Hy het nooit 'n gelowige paar ouers na 'n verwoestende haelbui gelowig hoor prewel „die Here weet beter" nie. (iv) Hy het waarskynlik nooit die verband tussen Kort Begrip-leerdery en ,,aanneming" verstaan nie. (v) Hy woon en werk van sy 16 de jaar af tussen mense vir wie hy meen om die feit van sy kerklidmaatskap sorgvuldig te moet geheim hou. (vi) Hy is vir 'n feit ingeprent, en hy kan nie anders nie as om eerlik te glo dat die ampsdraers van die kerk 'n skynheilige klomp is wat net in sy geld belangstel, ensovoorts. Wat sal woorde soos ,,sakramentsontheiliging”, ,wêreld- 
gelykvormigheid", „dag van saligheid”, „Vaderskap van God” hom sê? Hy kan bereik word alleen by wyse van 'n benadering wat sorgvuldig rekening hou met sy erbarmlike gebrek aan enige geestelike agtergrond hoegenaamd.

3 Onder ons volk in ons tyd is die verwaarlosing onder die jeug nie materieel nie, maar geestelik. Minder as $1 \%$ van die blanke kinders in S.A. het behoefte aan kos en klere. Maar wie sal die persentasie bereken van hulle wat gebrek ly aan liefde en beveiliging, en die wete van welkom te wees op die aarde, en opregte welmenende belangstelling, en onderrig en voorligting en voorbereiding vir wat voorlê? En is daar groter gebrek as dit? As 'n kind genoeg kos en klere kry, dalk selfs in oorvloed, maar niks meer nie, kry hy nie klippe vir brood nie? En is daar enige aanduiding dat die barmhartigheidsdiens van die kerk tot stoflike nood beperk moet wees? Ek herhaal: hier skreeu die wêreld, vir wie God liefhet, om barmhartigheidsdiens, diakonaat.

4. Natuurlik moet die kerk nie ophou nie om weerstand te bied teen die proses in ons volkshuishouding wat meer en meer die vaders deur werksomstandighede vreemdelinge in hulle eie huise maak, meer en meer die moeders bedags uit hulle huise weglok, en sodoende meer en meer die versorging van klein blanke kindertjies 'n aangeleentheid vir nie-blanke bediendes maak. Maar as die kerk tot die uiterste toe weerstand gebied het, moet hy ook realisties genoeg wees om te erken dat die proses meedoënloos voortgaan. En dan moet die kerk weë en middele vind om te midde van so 'n proses ook nog te kan uitgaan „,na die uiterste van die aarde" toe. Die tyd is oorryp dat die gemeente Vereeniging byvoorbeeld voorsiening maak vir 'n metode om altans sommiges van die letterlik honderde suigelinge en kleuters van Hervormde en ander Afrikaanse én anderstalige blanke ouers wat van 8-uur tot 5-uur elke dag aan die genade van nie-blankes oorgelaat is, vir daardie nege ure van elke dag, en altans sommiges van die honderde laerskoolkindertjies wat van 2-uur tot 5-uur elke dag aan die strate uitgelewer is, vir daardie drie ure, te versorg en te leer en te vorm. Watter wonder sal onvervulbaar wees as daar gedurende al hierdie tyd gesaai word, en as God instaan vir die wasdom? Kry ons duur kerksale met spogkombuise en al, nie dan darem 'n bietjie betekenis nie? En die staat en die nywerhede moet betaal. Húlle beoefen die roofbou wat die erosie meebring; húlle moet die bewaringswerksaamhede bekostig. Hier dring 1000 vrae hulleself op: Waar kom die personeel vandaan? En opgeleide personeel? Is dit die kerk se werk? Of die staat s'n? Of die nywerhede s'n? Ek kan weinig van hulle beantwoord. Die staat en talle nywerhede doen reeds iets in dié verband. Wat egter in ons gesprek belangrik is, is dat hier 'n geopende deur vir die 
kerk is, en as ons net ander instansies daar laat ingaan sal húlle die kindertjies na Jesus laat kom? Die staat? So soos in die skole? Of die nywerhede? Is daar ander instansies as die kerk wat barmhartigheidsdiens kán verrig? Maar hiermee is ek ver van die terrein van die Raad vir die Belydende Jeug af. Op watter kerklike terrein is ek hier eintlik? Diakonaat? In elk geval sien ek hier iets van die visioen van Ps. 78. En as die Raad vir die Belydende Jeug die kerk se greep na die jeug moet wees by alle ander instansies verby, dan is hier plek om te gryp. En dié greep kan beswaarlik minder wees as 'n eerlike poging van die kerk om die lugleegte te vul wat in die wêreld van die jeug geskep word deur die afwesigheid van hulle ouers. En nou, teologiese vrae: die kerk die moeder van die gelowiges? Rooms? Sucial Gospel? Verbode vrugte? "Laat die kindertjies na My toe kom, en verhinder hulle nie." En die vermaning hierin vervat, is gerig aan die adres nie van die moeders nie, maar van die dissipels.

5. Die jeug is glo besig om êrens, buitekant die kerk, „Christus te vind". En daar word aanspraak gemaak op talryke geslaagde ontworstelings aan verskeie vorms van verslawing. Hiervan moet die kerk met dankbaarheid kennis neem. (Net soos die kerk nie moet aarsel nie om met dankbaarheid te erken dat die sektes behulpsaam wás met die rehabilitasie van talle alkoholiste met wie ons radeloos was). „Daar is ook geen ander naam onder die hemel wat onder die mense gegee is waardeur ons gered moet word nie", as die naam van Jesus Christus. Maar hieruit moet die kerk hoogstens moed skep. Troos mag hy daar weinig uithaal. Want hier is volgens alle aanduidings ' $n$ vind van Christus buite die Skrif, sonder die Bybel. En dáár kan weinig heil van verwag word.

Feit is dat ons in 1971 die laaste stuiptrekkings van 'n bepaalde vorm van losbandigheid beleef. Die ongebreidelde, blêrkas-tipe van verdierliking is op pad uit. Ons staan voor 'n nuwe opbloei van die sentimentalisme. Sy eerste bloeisels was die blommegedweep van die hippies, sy gelaat begin dofweg sigbaar word in die rolprent "Love Story", en sy pretensies word voelbaar in hierdie nuwe Jesus-kultus. Of die kerk onder sy hoogty minder as gister en eergister sal hoef te versug: My volk gaan ten gronde weens 'n gebrek aan kennis, val te besien.

Maar die kerk móét ook ruimte laat vir die besef dat dit die Here vrystaan om enige dag na die jeug van die wêreld te gryp by die kerk verby...

6. Nog 'n ding wat, ook in ons volksgeskiedenis, aan't verdwyn is, is die idilliese fase waarin dit mode was om aan 'n kerk te behoort en voorbeeldig te lyk. Voorbeeldigheid soos ons hom 
geken het, devalueer nog vinnigèr as die dollar, en geen $10 \%$ bobelasting kan dié proses stuit nie. Dit word met kumulatiewe momentum onmoontliker vir ouers om hulle kinders „deur die aanneme te kry", waar hierdie poging die voorafgaande vorming daartoe deur persoonlike geloofserns, onderrig en voorbeeld moes mis. Lidmaatskap van die kerk word al méér wat dit altyd moes wees, naamlik resultaat van 'n persoonlike geloofsbeslissing. Die Afrikaner van die toekoms sal nie meer aan die kerk behoort net omdat sy ouers aan die kerk behoort het nie. Hy sal aan die kerk behoort alleen as hy tot dié geloofsbeslissing gebring is deur nougesette Woordbediening aan hom persoonlik, en deur die genade van God. Aan laasgenoemde hoef ons nie te twyfel nie, maar die Woordbediening aan indiwidu vir indiwidu is die taak van die kerk. Daar is nie 'n gunstiger tyd om dit te doen as van sy prille jeug af nie.

\section{RIGLYNE VIR DIE PRAKTYK.}

\section{Doelgerigter aksie langs 'n wyer front:}

Die Raad vir die Belydende Jeug is oortuig dat die arbeid van die kerk aan die jeug dringend sy vlerke veel wyer moet span as die sukkelende instandhouding van - en die volgehoue lewe inblasery in - die Jeugvereniging. Ons moet die evangelie by die kinders en die jeug kry - en ons moet dit só goed, só planmatig, so verantwoordelik doen, só met die aanwending van elke denkbare hulpmiddel, só ondanks enige opoffering wat dit van ons kant mag verg, só met gebruikmaking van elke greintjie vermoë van hoof en hart en hand waaroor ons beskik, dat ons darem met 'n mate van vrymoedigheid sal kan bid dat die Here ons pogings wil beloon met die wonder van die geloof in hulle harte en die opening van hulle lewe vir die vreugde van sy diens saam met die gemeente rondom Woord en Sakramente. En ons moet byvoorbaat ooreenkom om nie vir mekaar en vir onsself te sê dis die ouers se plig en wat dies meer sy nie. Natuurlik moet die ouers met krag op hulle verantwoordelikheid gewys word, maar, soos Karl Barth sê, dit staan in 'n ander hoofstuk. Ons moet dit eenvoudig doen by die ouers verby - as dit moet, ten spyte van die ouers, ten spyte ook, waar toepaslik, van die ouers se volgehoue onderrig aan die kinders te dien effekte dat die predikant en die ouderling en die diaken net altyd geld soek. Dit moet ons geloofswaagstuk wees om te gaan bewerkstellig wat in Ps. 78 as belofte opgesluit lê. En ons móét dit ten minste met die kinders en die jeug van die kerk bewerk. Watter hoop het ons om die wêreld te herkersten as die gedoopte, gekatki- 
seerde, bepreekte, ,aangeneemde” jeug van die kerk onder ons neuse en in ons hande kerklos, kerkloos, onkerks, buitekerklik word?

En wat moet nou die doelwit wees by hierdie be-oogde geïntensiveerde bemoeienis van die kerk met die ganse jeug van die kerk? Hopelik is dit vir almal duidelik dat om blind te volhard met aan te moedig tot, aan te dring op, te raas oor bywoning van die Jeugverenigingbyeenkoms op een of twee weekaande per maand nie deug nie. Ons moet vergeet om mense met geen of weinig kerklike belangstelling geinteresseerd te kry in 'n kerklike vereniging. Daar's vir hulle te veel boeiender afleiding beskikbaar. Ons moet begin by hulle belangstelling in en hulle meelewing met die kerk. Ons moet hulle in die kerk kry. Ons moet aandring op uitvoering van die belydenisbsloftes „om by hierdie belydenis deur Gods genade te bly, die sonde te versaak, en 'n Christelike lewe te lei," en "om saam to werk tot die bloei van die Godsryk in die algemeen, en die Ned. Herv. Kerk in die besonder," want hiervoor het hulle ook „van God en sy heilige gemeente" hulle „onderwerp aan die kerklike opsig en by geval aan die kerklike tug", dit wil sê hulle het hulle in ons hande gestel. En hulle het dit onvoorwaardelik gedoen. Dáár lê ons aanknopingspunt.

Die Raad vir die Belydende Jeug beoog 'n volgehoue verskerpte planmatige bemoeienis met die ganse jeug van die kerk ten einde te probeer bereik dat die jeug van die kerk sy belydenisonderneming sal nakom, maar wat belangriker is, sodoende weerbaarder sal wees teen al die verwoestende invloede wat hom bedreig, en, wat die heel belangrikste is, in dié proses ook 'n kragtige getuienis lewer van die bevrydende en behoudende krag van die evangelie van Jesus Christus. Op dié wyse meen die Raad, sal hy iets gedoen hê aan sy opdrag vanweë die kerk om ten eerste „voorligting te gee hoe om die jeug aktief te betrek in die lewe van die gemeente en die kerk" en juis sodoende ten tweede "leiding en voorligting" te gee ,in die toerusting van die jeug van die kerk wat reeds belydenis van die geloof in die gemeente afgelê het, vir hulle dienswerk in die wêreld."

Maar hoe word dit gedoen?

Die gestelde doel sal nie bereik word deur gepubliseerde oproepe in "Die Hervormer" nie - want die jeug lees hom nie; ook nie deur aankondigings in "Kerknuus” oor die radio nie want die jeug hoor dit nie; ook nie deur gloeiende redevoerings van die kansel af nie - want die jeug is nie daar nie; die persentasie van die jeug wat op dié maniere bereik kan word, verskaf 
ons nie kommer nie, want hulle kerklike meelewing voldoen reeds in meerdere of mindere mate aan die doelstellings in die vorige paragraaf aangehaal. Die vraag is hoe om die ander $85 \%$ te bereik?

En daar is maar één antwoord: hulle moet bereik word. Daar moet na hulle gesoek word. Iemand moet agter hulle aanloop, tot in hulle woonplekke, agter hulle aan inkruip, tot waar hulle wegkruip. 'n Lewende mens moet gevind word wat bereid sal wees om, as hulle 'n myl van hom afdwing, twee myl met hulle saam te loop, en hulle mee te deel dat hulle nie hoef slawe van die duiwel te wees nie, nie hulle deur die duiwel hoef te laat voorsê om hulle geluk te verknoei en hulle toekoms te vertoiing nie, dat hulle vry mag wees van hierdie slawerny, vry in Jesus Christus om vir God ja te sê op sy aanbod van die volheid en heelheid van mens-wees deur sy Woord en Gees. En dit moet hulle meegedeel word op so 'n wyse dat hulle deur die waarheid daarvan oorweldig sal word, dié mededeling sal aanneem, en deur die aanname daarvan ook vry sal wórd, en sodoende ook weerbaar, en sodoende weer op hulle beurt getuies.

Maar dis makliker gesê as gedaan, nie waar nie? Moet óns dan verantwoordelikheid aanvaar vir die aanname van ons verkondiging? Dis mos die Heilige Gees se werk! Wat 'n verruklike teologiese appel, die van die Heilige Gees. Poeding vir ons teologiese aptyt - en Adam en Eva bly maar honger. As die Heilige Gees maar net sy werk wil doen! Kyk hoe maklik is dit dan: Paulus sê net: "Glo in die Here Jesus Christus, en jy sal gered word, jy en jou huis," en daar verander 'n gevoellose Romeinse monster in 'n sagsinnige, voorbeeldige Christen. Ja, maar voor daardie paar woorde van Paulus speel 'n ontsaglike geskiedenis hom af tussen Paulus en hierdie man, 'n geskiedenis waarin Paulus in een nag bereik wat ons 'n leeftyd gegun word om te probeer benader, naamlik dat die ander man die oomblik wanneer jy meedeel, geen sweem van twyfel meer het oor die betroubaarheid van wat hy van jou gaan te ontvange kry nie. Inteendeel hy pleit reeds bewend voor jou om mededeling van die geheim van jó krag. Die lewende mens wat hy in jou aanskou en leer ken het, het vir hom die bewys geword van die waarheid van wat jy hom meedeel. Dit doen die Heilige Gees, en ook die res, onvoorwaardelik.

Siedaar! Die geheim van suksesvolle kommunikasie, mededeling, oordrag van geloofsinhoude van mens tot mens.

Nou weet ons dus hoe dit gedoen moet word.

Maar wie moet dit doen? 
Gelukkig beskik die kerk vandag oor 'n korps van nagenoeg 9000 man wat gereed staan om dit te doen, 9000 man gebonde deur ' $n$ formulier om dit te gáán doen, 9000 man wat in elk geval gereeld agter die jeug aanlo:sp tot by hulle woonplekke, agter hulle aan inkruip tot waar hulle wegkruip. Dis sy predikante, ouderlinge en diakens. Hopelik hoef ek nie te motiveer dat die jeug en die kinders ingesluit is by die opdrag aan predikante en ouderlinge nie. En hopelik hoef ek na die veelvuldige verwysings hierbo na die diakonaat ook nie die insluiting hierby sonder meer van die diakens te regverdig nie.

In hierdie formidabele slagorde beskik die kerk oor al die potensiaal wat hy kan begeer om al die tienduisønde jongmense cn kinders in sy gesigsveld te bereik, en aan hulle mee te deel wat Paulus die sipier van Filippi meegedeel het.

Nou weet ons ook wie dit moet doen.

Maar wat behels dit nou?

Dit behels ten eerste dat die ampsdraer-korps van die kerk oog kry vir die jeug. Die lidmate van 'n wyk is nie net die volwassenes nie, maar ook, en in geen blou duit mindere mate nie, elke afsonderlike jong mens en kind, tot die suigelinge toe. 'n Ampsdraer het nie sy bediening vervul as hy huise besoek het nie, maar eers as hy elke afsonderlike mens gedien het op die wyse wat ek hierna sal probeer aandui. Wat nodig is, is die geroepe bereidheid by die ampsdraers van die kerk om, waar dit kan, met behulp van die ouers, en waar dit moet, by die ouers verby, deel te word van die greep van ons kerk na die jeug van kerk en volk. Dan word ons jeuggerig langs die hele linie van die ampsbediening van die kerk. Dan is ons nie meer tevrede as ons in hulle huise was, en miskien hulle ouers "gesien" het nie. Dan dring ons daarop aan om hulle, die afsonderlike mens wat elke jeugdige is, nie alleen te ,sien” nie, maar inderwaarheid te bereik.

En as ons hierop aandring, behels dit ten tweede die bereidheid by die ampsdraers van die kerk om hulleself te géé in 'n persoonlike verhouding met elke jong mens en kind, waarin en waardeur, miskien langs die pad van baie jare, met hierdie jongmens en kind sal gebeur wat met die sipier van Filippi in een nag gebeur het, naamlik dat die oomblik wanneer jy jou mededeling aan hom doen, hy geen sweem van twyfel meer het oor die betroubaarheid van wat hy van jou gaan te hore kry nie. Die goeie God self lei eers sy volk uit die slawehuis uit, en vra dan gehoorsaamheid aan sy wet. Vir ons ampsdraers van die kerk, om te wil gesag uitoefen oor diegene vir wie ons nie gedien het nie, is onchristelik, én onbeskof, én onnosel. 
Dis hierdie dinge waaroor die Raad vir die Belydende Jeug by die sogenaamde jeugleidingskursusse in al die Ringe van die kerk graag met al die ampsdraers breedvoerig wou en wil praat na aanleiding van die onderwerp: Die verhouding ampsdraer en lidmaat, en die vereistes vir suksesvolle kommunikasie. Aangesien egter by die 9 kursusse wat reeds gehou is kwalik 90 van die genoemde 9000 ampsdraers teenwoordig was, vra ek hiermee $u$ geduldige aandag vir net een paragrafie nou hier, waarin hierdie lyn deurgetrek word tot op die grond.

'n Ampsdraer moet die jong mense en kinders in sy wyk ken, by name. Hy moet vir hulle tyd hê. Hy moet met hulle rekening hou. Hy moet hulle ernstig neem. Hy moet hulle roep, vir hulle wag. In hom moet hulle ondervind dat hulle vir die kerk bestaan, dat hulle vir die kerk tel ,as persone, elkeen afsonderlik, en nie as blote nommers nie. Hy moet in hulle belangstel, in hulle seer tone, in hulle nuwe speelgoed; in hulle skoolwerk en in hulle sportprestasies of -teleurstellings, in hulle besondere aanleg en talente, in hulle eerste romanses, in hulle toekomsplanne, in hulle liefdes en drome, in hulle werk en probleme, in hulle vreugde en ellende - soos in die van sy eie kinders. En as hulle al rondlopers geword het en vir hom wegkruip of wegvlug, dan is dit omdat hy, of 'n ander ampsdraer vóór hom, dit nie gedoen het toe hulle nog klein was nie. Nou vertrou hulle hom nie. Dan moet hy húlle voorlopig maar laat vlug, en met die kleintjies begin wat nog nie vlug nie, sodat hulle nie ook môre en oormôre vlug nie. Hy moet hulle in staat stel om hom te leer ken, sy belangstelling te waardeer en hom lief te hê. Hy moet nie met hulle foutvind voor hulle nog vertroue in hom het nie.

God gee die kerk in elke tyd - genadiglik - kindertjies om 'n nuwe begin mee te maak, sodat iets van die brandende visioen van Ps. 78 werklikheid mag word in die wêreld.

\section{Toegespitste konsentrasie op 'n kleiner groep.}

Wat voorafgaan, het te doen met die normale ampsbediening van die kerk in sy betrokkenheid op die jeug. Wat volg, het die oog spesifiek op die sogenaamde jeugwerk van die kerk, dit wil sê besondere bemoeienis met die jeug. Hier pleit die Raad vir Belydende Jeug vir meer differensiasie in ons benadering van die werk, en daarmee word bedoel die opleiding van die jeug van die gemeente in 'n aantal kleiner, meer homogene groepe. Want niemand kan meer onduidelikheid daaroor hê nie dat dit taamlik sinneloos is om die 14-jariges en die 24-jariges saam een of twee keer per maand 'n aand lank te wil vrugbaar besig hou. In plaas daarvan word voorgestel kleiner groepe byvoorbeeld die matrikulante, die $\mathrm{katkisante,} \mathrm{verlede} \mathrm{jaar} \mathrm{se} \mathrm{katkisantegroep}$ 
in Veree niging selfs meer as een vakleerlinge-groep, 'n groep verloofdes, jong getroudes, ensovoorts. Natuurlik sal daar nie ondeurdringbare skandmure van skeiding tussen die groepe wees nie. Inteendeel hoe meer hulle vriende en vriendinne oor en weer saambring, hoe beter. En van tyd tot tyd sal daar ook geleentheid wees vir gesamentlike byeenkomste van almal of sommige van die groepe.

Dit bring die eis mee van veel meer besinning en planmatigheid in die werksaamhede. By 'n matrikulantegroep sal die keuse van 'n toekomstige loopbaan byvoorbeeld veel meer belangstelling kry as by 'n vakleerlinggroep. Laasgenoemde het immers klaar gekies. Vir hulle sal leiding met betrekking tot voorsiening en voorsorg vir toekomstige behuising byvooorbeeld 'n saak van dringende erns wees. Maar onder hulle omstandighede sal die klem moet val op die oorwegings wat vir gelowige mense gewig behoort te dra in die onderskeie verbande.

Maar dit beteken op sy beurt die behoefte aan veel meer en veel beter toegeruste mense om leiding te neem, as waartoe die predikant en die ouderling vir jeugwerk in staat is. Elke groep behoort 'n leier of leierspaar te hê wat die verantwoordelikheid by al die verrigtinge dra. En hiervoor is daar in elke gemeente mense wat uitnemend geskik is - op voorwaarde dat hulle onder leiding van die predikant en die ouderling vir jeugwerk daarvoor toegerus word. En vir húlle kan dit geweldige geestelike verryking beteken. So 'n leierspaar, verkieslik 'n onderlegde verloofde of jonggetroude paar vergesél dan byvoorbeeld 1971 se katkesantegroep van hulle sewentiende tot om en by hulle $23 / 4$ ste lewensjaar. Wat kan dit nie na albei kante beteken nie. So 'n paar jong mense se woonplek kan 'n tweede - en in baie gevalle dalk in werklikheid 'n eerste - ouerhuis word vir jongmense wat weinig ander ervaring van huislike geborgdheid sou kon opdoen.

Nodeloos om te sê dat veel van die optimisme in dié verband spruit uit kennisname van die welslae wat resultaat is van die spanwerkmetode in onder andere die Voortrekkerbeweging.

Hieroor wou en wil die Raad vir Belydende Jeug graag breedvoerig praat by die Jeugleiding-kursusse aan die hand van die onderwerp: Die aanwending van alle moontlike hulpmiddels byvoorbeeld groepdinamika, vryetydsbesteding, gesellig verkeer, uitstappies ensovoorts.

Vergun my asb. in die verband nog enkele tersaaklike aanmerkings:

(i) As dit in orde is met die kategese, prediking en opsig, dit wil sê met die normale ampsbediening van die kerk aan al sy doop- en belydende lidmate, deel ek persoonlik nie die vreeslike 
drukte oor nog bykomstige Bybelstudie, voortgesette kategese, ensovoorts met die jeug nie. As persooonlike Bybellees, huisgodsdiens, kategese, prediking en ampsbediening nie toereikende onderrig is nie, moet dit nie liewer opgeknap word nie? Of moet dit aangevul word met Bybelstudie vir 'n handjievol getroues op Donderdagaand? (Wat tog maar die handjievol is oor wie daar nie kommer is nie). Waarby sou die hele gemeente die meeste baat? Is ons nie besig om 'n mosie van wantroue in ons eie prediking te stel nie? As die prediking sou lei tot huisgodsdiens en persoonlike Bybellees en as persoonlike Bybellees, huisgodsdiens, kate. gese en ampsbediening sou uitmond in die erediens, en as ons dan die jongmens een of dalk twee keer per Sondag in die kerk kon bring, sien ek geen rede om 'n paar van die getroustes van hulle nog Donderdagaand ook te bespreek nie. Om hierdie rede het ek jare gelede reeds gepleit vir integrasie van huisgodsdiens, kategese en prediking, wat in die praktyk sou begin met die konsolidasie van die Bybelse Dagboek, die Kategese-lesrooster, Weiding en „Die Hervormer”. In 1967 het die Algemene Vergadering hieroor ook 'n duidelike besluit geneem waarvan sover ek kan sien, nog niks gekom het nie.

(ii) Daar word van verskeie kante met ontroerde heftigheid en verbysterende regsinnigheid beswaar gemaak teen wat dan neerhalend bestempel word as kampeerdery in die veld, naweekuitstappies, aanleer van boomname, ensovoorts as synde onwaardig, nie-teologies, nie die taak van die kerk nie, ensovoorts. Moet ons die Here Christus sy optrede in die verband so verskriklik kwalik neem? Hy beskik oor die kennis - en Hy het maar drie korte jare tyd - om ons so ontsaglik veel van teologiese belang mee te deel oor hemel en hel en alles wat daarmee gepaard gaan. Hoeveel daarvan laat Hy nie ongesê nie? En in plaas daarvan ,verspil Hy soveel van die kosbare tyd" om stil te staan by die eerste lentebotsels aan die vyebome, die lelies van die veld, die voëls van die hemel, twee mossies wat op die mark vir 'n stuiwer verkoop word. En laat ons in die verband vra: As die onderhawige gebeure hom in ons tyd in Pretoria afgespeel het, waar sou die Tuin van Getsemane „waar Jesus dikwels (d.w.s. graag) met sy dissipels saamgekom het", geleë wees? Dalk by die Fonteine? Of nog erger, skrikwekkende gedagte, besmoontlik by die Pienaarsrivierdam?

(iii) Die mensdom het behoefte aan leiding met betrekking tot 'n omvattende greep op die verskynsel van lewe en dood op die aarde, en die jeug uiteraard met meer nadruk op die lewe as op die dood. Skort daar iets aan die vermoë van die evangelie om ten volle hierdie behoefte te vervul? Is dit werklik so 'n 
onverbiddelike eis van die regsinnigheid dat die kerk in sy prediking, ampsbediening en bemoeienis met die jeug hom sal laat inkerker in die éên idioom van sonde, siel en saligheid? Of is dit gemaksug? Of het ons tog toegelaat dat die Liberalisme óns hier vaspen, sodat die ganse terrein van die lewe van die mense van Maandag tot Saterdag bloot en weerloos sal wees voor sy boodskap van gelykmaking, uitwissing van grense, „Love and charity?" Skuld ons dit nie ten duurste aan die mensdom nie om in diepe verantwoordelikheid die beslissing van die geloof te vel, en met die lig van die evangelie in prediking, ampsbediening en bemoeienis met die jeug, op die kansel en daarvan af, saam met hulle die donker te lyf te gaan op al die terreine waar dit heers: volk en vaderland, politiek en kultuur, werk en geld, sport en spel, seks en liefde en dies meer? Of het die belofte: „om saam te werk tot die bloei van die Godsryk in die algemeen en die Ned. Herv. Kerk in die besonder" met al hierdie goed niks te make nie?

As die grootkapitaal van ons magtige teologiese insigte nie, oor die toonbank van prediking, ampsbediening en voorligting aan die jeug, uitgewissel word in die vorm van geldige munt, bruikbare kleingeld, waarmee hulle hulle passaat deur die wêreld kan betaal nie, dien al ons teologie geen doel nie. Maar voordat dit kan gebeur, móét daar onontwykbaar eers 'n geweldige gebeure homself in die teologie voltrek, naamlik dat die ongenaakbare verhewenheid van verontwaardigde Ou Testamentiess profete gepuur word tot die deernis van die evangelie van Jesus Christus. In die Bybel hêt dit gebeur, langs die pad van die plaasvervangende lyding van Christus aan die kruis. In óns hoef dit slegs te gebeur in die uitgaan uit ons ivoretorings van al. wetende regsinnigheid, en die ingaan in die smeltkroes van onvoorwaardelike medelye met die mense van ons tyd. En miskien sal dít óns ook blootstel aan die verwyt Mark 2:16. Of ons egter dié verwyt moet vrees, is twyfelagtig, solank ons maar bewus is van die onderskeid tussen die "tollenaars en sondaars" van Mark. 2:16 en die ,dronkaards" van Matt. 24:49.

(iv) Watter evangelie moet die kerk aan die jeug van die permissiewe gemeenskap verkondig? Die van ,voorkoming is beter as genesing"? En sou dit dan sinoniem wees met „voorkoming is beter as vergewing"? Maar kán dít? Is daar hoegenaamd 'n ,evangelie van die voorkoming van sondes"? Die broers van die Praktiese Teologie sal kerk en wêreld 'n ontsaglike diens bewys deur leiding te gee met betrekking tot die sielsorgerlike en ander implikasies van hierdie vraag. 


\section{E. DIE VOORTBESTAAN VAN 'N VERENIGING.}

As die broeders, en die kerkrade, en die kerk, op die wyse soos hierin aangedui, of op 'n ander, besmoontlik veel beter wyse, met die vindingrykheid van die geloof en die volharding van geloofsgehoorsaamheid, deelneem aan die greep van die kerk na die jeug, laat die Raad vir Belydende Jeug dit graag aan die wysheid van die bevoegde instansies oor om te besluit oor die wenslikheid aldan nie van die voortbestaan van die N.H.J.V. soos ons hom ken. Maar ons mág alleen bestaande middele afskaf as die motief is om dan op 'n ander manier beter en harder en sinvoller aan dieselfde saak te werk. 